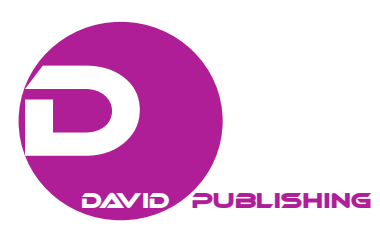

\title{
A Roman Funerary Monument From Šipovo
}

\author{
Radmila Zotović \\ Institute of Archaeology, Belgrade, Serbia
}

\begin{abstract}
A newly discovered Roman funerary monument from Šipovo mentions a Roman urban settlement in the municipium rank with the name not identified to date apart from the three initial letters-Bal. The deceased was both in military service as a centurion and in civil service as a decurion of the mentioned town. That it was a person of importance is indicated not only by the gravestone inscription but also by the relief depiction of the deceased, shown to be holding a volumen in his hand. Since the monument is chipped and damaged in the upper part, it can only be determined that it was a stela type funerary monument. The main goal of this work is to underline the importance of this monument as a great archaeological treaser, since it is the first written source from Roman period for the town with the three initial letters-Bal, as well as the source for further excavation and the researching of military units of the first word Nova. Two questions will stay open: when the settlement becomes municipium, and the full name of the town.
\end{abstract}

Keywords: Roman period, funerary monument, the first mention of municipium Bal, military units of Nova word, centurion, decurion

\section{Introduction}

It was a while ago in Šipovo, during the works on enlarging an Orthodox church building, that a Roman funerary monument was uncovered. This monument has a great scientific significance since it is the first mention of the Roman town of municipium rank with the three initial words-Bal.

The main goal of this work is to analyse this funerary monument. The analysis of every funerary monument considers the type of the monument, description of the same, reading of the text, and researching of the text meaning. The further analysis is to discuss about the main facts which the text may consider and to date monument.

\section{A Roman Funerary Monument From Šipovo}

The funerary monument is of stela type. It was made of limestone and was rather damaged in the upper part. A part of the relief field is visible, as well as the inscription field and the socle beneath the inscription field with a part of the tenon (Figure 1). Since the upper part of the relief field is damaged, and the pediment is chipped, the stela type that the funerary monument from Šipovo belongs to cannot be identified with certainty. It is only by its dimensions $(0.46 \times 1.40 \times 0.13 \mathrm{~m})$ that it might be said to belong to the type of stelae with one relief field and the inscription field beneath it. Both the relief and inscription fields are framed by a simple triple moulding with no ornamental elements. A remnant of an ornamental element is visible in the socle

Radmila Zotović, Ph.D. of Classical Archaeology, Institute of Archaeology, Belgrade, Serbia.

Correspodence concerning this article should be addressed to Radmila Zotović, Institute of Arcaeology, Knez Mihailova 35/IV, 11000 Belgrade, Serbia. 
beneath the inscription field. The inscription field (dimensions $0.45 \times 0.56 \mathrm{~m}$ ), at the bottom below the text, shows a relief depiction of a leaf. The preserved part of the text reads: $D($ is) $M$ (anibus)/P Ae(lio) C(enturio)/Nova [-----]/dec(urio) mun(icipii)/Bal()/[------]MO (see Figure 2).

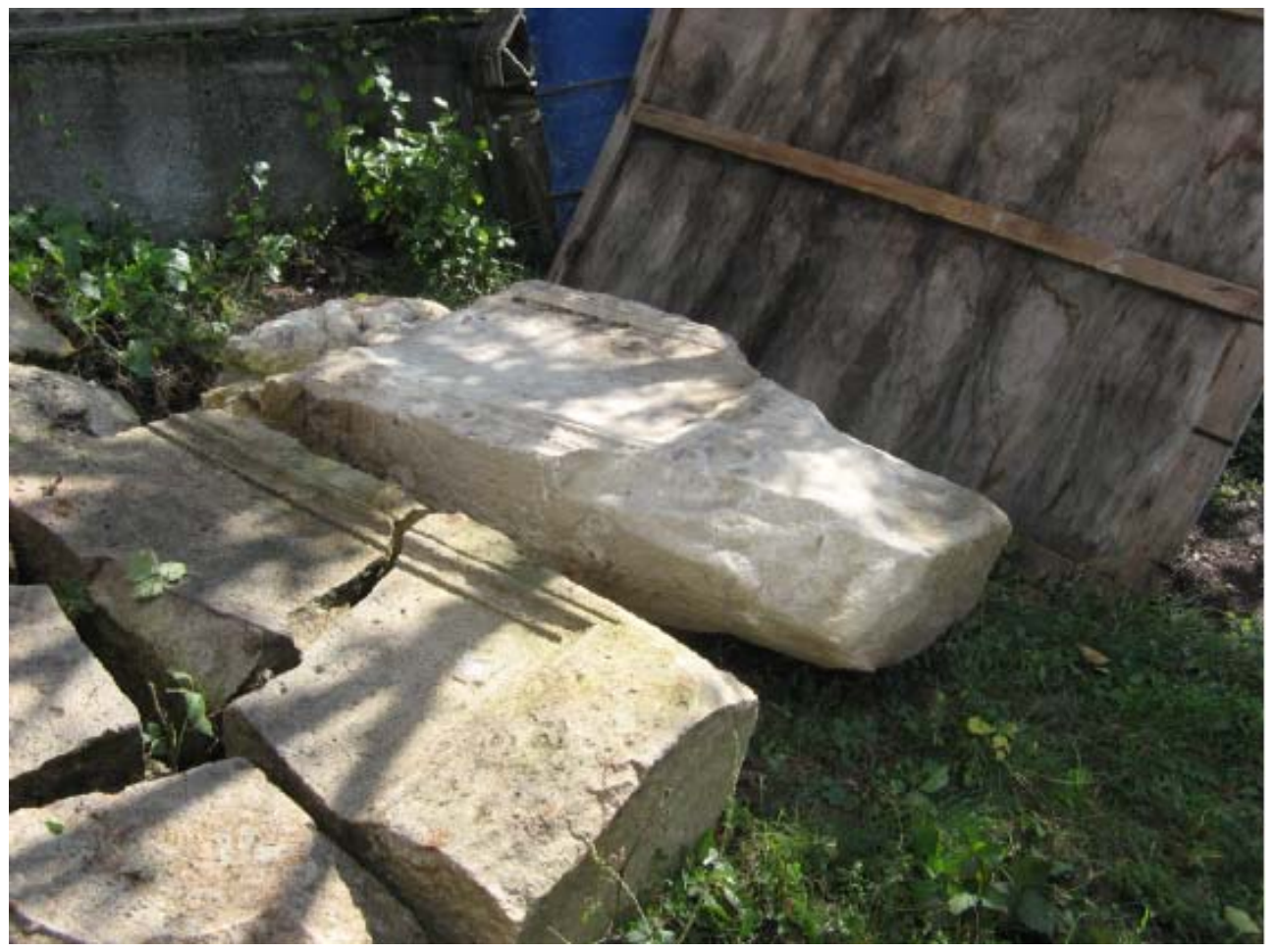

Figure 1. Септембар 201031.

\section{Discussion About the Main Facts}

In the relief field a remnant of the relief depiction of a male bust is visible. The man is depicted in a toga, holding a volumen in one hand, and the hand of the other arm, folded at the elbow, rests on his chest. Although the text is rather damaged, the very fact that the man was depicted with a volumen in his hand indicates that it was most probably a military man of higher rank, or it may be an indication of citizenship status (Сf.: Зотовић, 1995). More precisely, regardless of whether it was a civilian or a military man, a volumen in hand always represents, and it is usually seen as an attribute for citizenship, since the Roman citizenship status in the military was received by higher ranks, i.e., when they were promoted from the rank of decurio cohortis or higher. As for civil service, in order to achieve social standing and office, persons needed to have a citizenship status. In this case, the person from the grave monument had successive offices: first in the military, as a centurion, and then in civil service as a decurion of a municipium of the unknown name starting with letters $B A L$. 


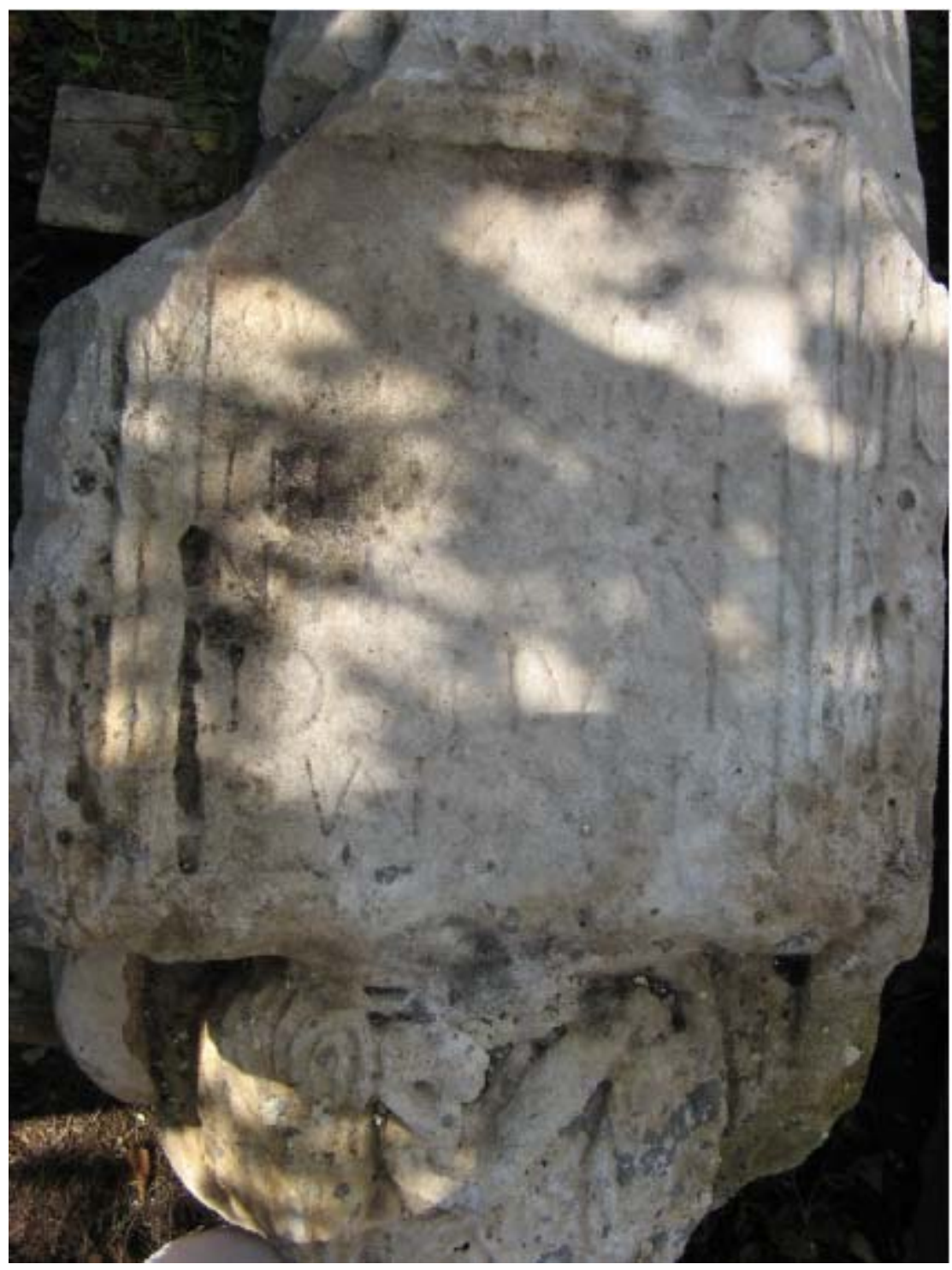

Figure 2. Септембар 201126.

\section{Previously Historical and Archeological Researching, the Dating and Main Facts of the Position of the Town}

As far as the author of this paper knows, this is the only epigraphic monument from the territory of Bosnia and Herzegovina that mentions a municipium with the first three letters being $B A L$. It is possible that the name of the municipium refers to the municipium later mentioned by Porphyrogenitus in vulgarised Latin as Bó $\gamma \mathrm{k} \varepsilon 1 \zeta$, Bó $\gamma k \varepsilon ı \varsigma$, and В $\alpha \lambda \beta \eta \varsigma$ (Баришић \& Марковић, 1955).

Bojanovski believed that in this area there was a Roman municipium Baloie (Bojanovski, 1974). He actually linked the name of this municipium to the civitas rank settlement mentioned in the sources as a travel station, civitas Baloia (Bojanovski, 1974). According to Wilkes, this urban settlement in the river Pliva valley was in accord with the municipium rank during the reign of Emperor Hadrian (Wilkes, 1969). Later historical sources (Bojanovski, 1974) mention that the town was conquered and destroyed in late 6th century, at the time of Maurice (582-602). The name of this town appeared in several written "variants", but they are thought to 
present different vulgarised forms of Latin and actually refer to the same town. This in particular refers to similar names of this town, such as Balcam, Baleam, Balea, and Baloiam, which all correspond or may correspond to the town called Baloie. The same refers to mentioned names of the conquered town as Balca,

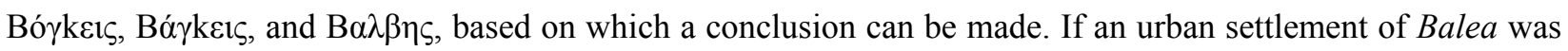
identical with Baloie, then the mentioned names of the conquered town may be considered as names that also refer to the municipium of Baloie (Bojanovski, 1974).

Going back to a further analysis of the discovered monument from Šipovo, it may be seen that the name of the deceased, Publius Aelius, is of the so-called two-part onomastic formula type, where the gentilicium Aelius points to the period of achieving citizenship rights in 2nd century, most probably at the time of Hadrian or Antoninus Pius. The two-part onomastic formula also points to a person (most probably of native origin), who himself or through "inheritance from father to son" acquired citizen rights and received a name from the Latin name repertorium. Since the deceased had a lifespan of 50 years, this funerary monument may be dated into a broader chronological framework of 2nd century. It is believed that in the area of Šipovo, near Zenica, there was a significant stone carving production (Paškvalin, 2012). More precisely, it is thought that in the territory of Baloie municipium there must have been a local carving workshop for producing stone monuments (Cambi, 1982).

\section{Military Units and the Profession of the Deceased for His Life}

Military units whose names mention the attribute Nova are the following ones: ala I Claudia Nova Miscellanea, cohors II Aurelia Nova Milliaria Equitata Civium Romanorum, cohors VI Nova Cumidavensium Alexandriana, cohors I Aurelia Nova Pasinatum Civium Romanorum Milliaria, and cohors I Aurelia Nova Sacorum (Beneš, 1978). Except for the ala Claudia Nova Miscellanea and the cohort VI Nova Cumidavensium Alexandriana, whose operations in the territories of Dalmatia and Dacia are linked to the periods of 1st and 3rd centuries, the mentioned military units were identified in the epigraphic monuments that may be dated into the period of 2 nd century. It is thought that stationing of military units in the 2nd century was related to stationing along the border of Moesia Superior and Dalmatia (Beneš, 1978). Thus, for instance, Beneš gives an example of the cohort I Aurelia Nova Asacorum that was assigned to the territories of both Dalmatia and Moesia Superior provinces (Beneš, 1978). Earlier on Patsch also thought that the influence of Roman in the river Pliva valley was primarily of military character (Patsch, 1910), and Sergejevski believed that the military camp that was used by and built for a cohort became an urban settlement later on (Bojanovski, 1974). In order to avoid any confusion, given that Dalmatia was a province inarmis, i.e., with no military, from AD 70, Sergejevski states that this small camp existed in the 1st and 2nd centuries, while Bojanovski claims that in both 2nd and 3rd centuries in the area of Šipovo only auxiliary military units were situated (Bojanovski, 1974). Nonetheless, in the entire territory of Bosnia and Herzegovina the monuments where military units are mentioned are not numerous. Mostly smaller military units are mentioned, while legions are mentioned in fewer monuments. For the most part leg. II is mentioned, with no name indicated (Paškvalin, 2012). In addition, leg. XI Cl(audia) p(ia) f(idelis) (Paškvalin, 2012), VIII Aug(usta) (Paškvalin, 2012), leg. P(rimae) I(talicae) p(iae) f(idelis) (Paškvalin, 2012), as well as leg. VII, possibly Claudia (Paškvalin, 2012) were also mentioned. Smaller military units were mentioned including cohort III Alp(ina) (Paškvalin, 2012), I Luce(nsium) (Paškvalin, 2012), I Bracaraug (Paškvalin, 2012), and cohort I Belgarum (Paškvalin, 2012). Such a "list" of the mentioned military units should by all means include also the newly discovered one from the Šipovo monument, for which it cannot be 
known as well, for the time being, its exact identification, i.e., the full name of this military unit. The fact that the said Publius Aelius (see Figure 3) was at first an officer in a military unit does not conflict with the monument dating and the fact that Dalmatia was a province inarmis from as early as AD 70. Not surprisingly, once they left the military or the term of their service was over, military persons could take up civil service in any area, not only where the military unit in which they had previously served was stationed in. If their personal financial security allowed it, they would join in the civilian social life mostly by becoming members of the city council, and continued their service by deciding on the urban utility network and infrastructure as well as on town ornaments. Such functions that are mentioned one after the other are thought to be the so-called "successive" functions. Analysis of epigraphic material for the territory of Roman Serbia showed that the largest number of such functions actually involved the relation military service-decurio (Zotović, 2007). There are examples that after ending military service they moved even from rather distant parts into the territory of a specific municipium that may be found, for instance, in the territory of Serbia. Thus a former high official of coh. I Thracum Syriacae and a tribune of the legion VI Ferratae moved into the area of Ravna (Timacum Minus), as stated on the monument in Syriae (This is mentioned as one of the most impressive examples, see: Zotović, 2007). Therefore it may be concluded that the area of this municipium was included in the general social mainstream of Romanisation as well, characteristically since the period of Hadrian (117-138) and later on, during the 2 nd and 3 rd centuries.

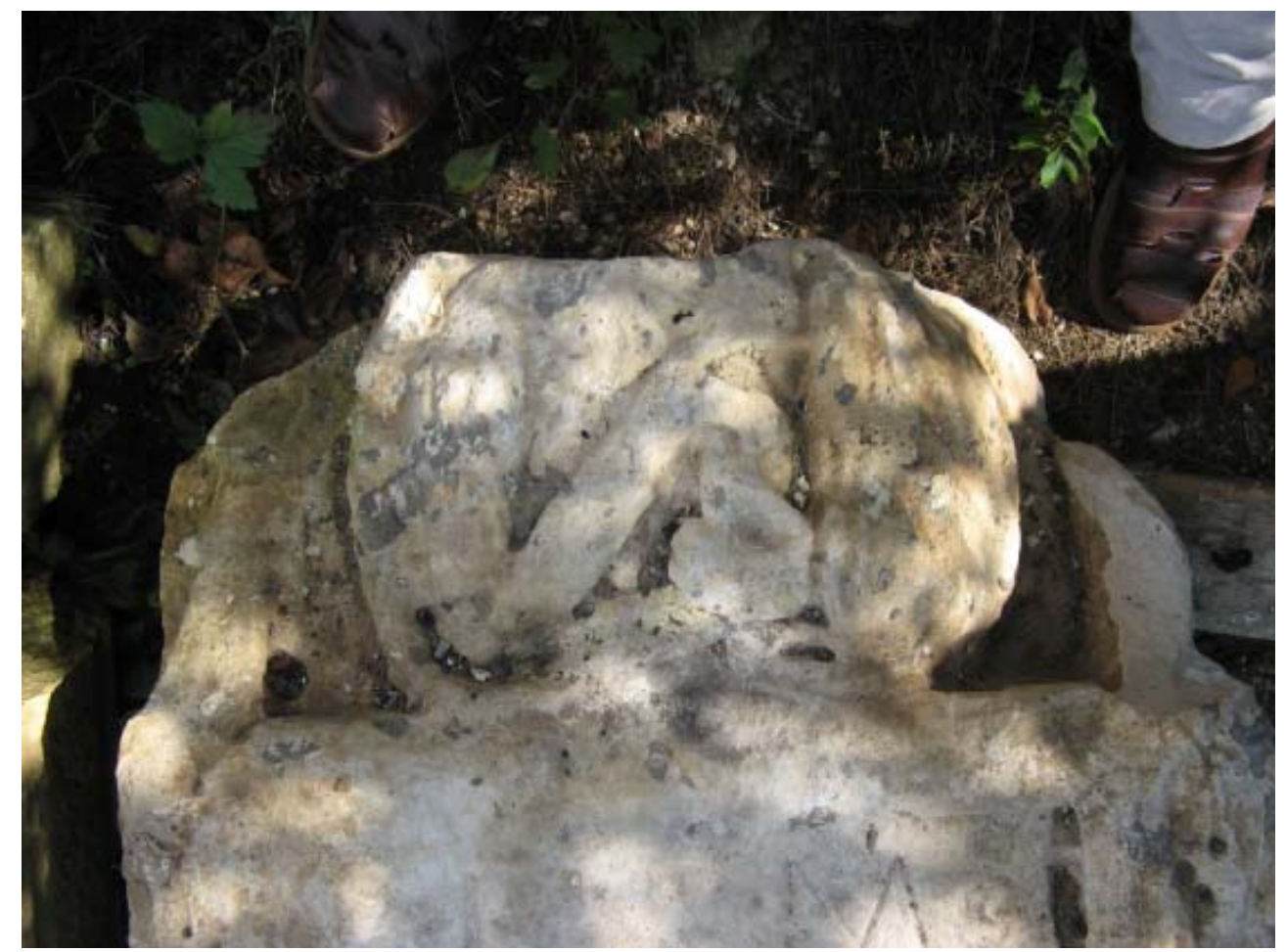

Figure 3. Септембар 2010025.

\section{Conclusions}

A newly discovered Roman funerary monument from Šipovo mentions a Roman urban settlement in the municipium rank with the name not identified to date apart from the three initial letters-BAL. The deceased was both in military service as a centurion and in civil service as a decurion of the mentioned town. That it was 
a person of importance is indicated not only by the gravestone inscription but also by the relief depiction of the deceased, shown to be holding a volumen in his hand. Since the monument is chipped and damaged in the upper part, it can only be determined that it was a stela type funerary monument.

The monument can be dated in the time of wider period of 2 nd century. There are two questions which will stay open for now: the time when the settlement becomes municipium and the full name of the town. It is possible to suggest that deceased for his life came for the smaller or further distance and became decurio of the town.

\section{References}

Баришић, Ф., \& Марковић, М. (1955). Византијски извори за историју народа Југославије I. Београд: Научна књига, $103-126$.

Beneš J. (1978). Auxilia Roman in Moesia atque in Dacia: zu den Fragen des römischen Verteidigungssystems im Unteren Donauraum und in den angrenzenden Gebieten. Praha: Academia.

Bojanovski, I. (1974). Baloie-rimski municipij u Šipovu na Plivi. Arheološki radovi i rasprave, knj, 7, 349-366.

Cambi, N. (1982). Sarkofag iz Šipova. Godišnjak Centra za balkanološka ispitivanja, knj, XX 18, 91-110.

Patsch, C. (1910). Prilozi našoj rimskoj povjesti. Glasnik Zemaljskog muzeja XXII, 101-190.

Paškvalin, V. (2012). Antički sepulkralni spomenici s područja Bosne i Hercegovine. Sarajevo Akademija Nauka i Umjetnosti Bosne i Hercegovine (Sarajevo: Dobra knjiga).

Wilkes, J. J. (1969). Dalmatia. Cambrige: Harvard University Press.

Зотовић, Р. (1995). Римски надгробни споменици источног дела римске провинције Далмачије.Ужице Кадињача.

Zotović, R. (2007). Gradja za proučavanje društvene hijerarhije na tlu Srbije u periodu rimske ladvavine (Material for Studying Social Hierarchy in the Territory of Serbia in the Period of Roman Government). Beograd Arheološki institut/Belgrade Archaeological Institute. 